\title{
Colonisation of orchids on the Krakatau Islands
}

\author{
Tukirin Partomihardjo
}

\begin{abstract}
Partomihardjo, T. (Bidang Botani, Puslit Biologi-LIPI, Jalan Juanda 22, Bogor-Indonesia) 2003. Colonisation of orchids on the Krakatau Islands. Telopea 10(1): 299-310. Orchids are the most diverse and attractive of the flowering plant families. Most of them grow as epiphytes. In forest communities of the Krakataus, Indonesia, epiphytic orchids are more abundant than terrestrial ones. However, during early succession of the Krakataus, terrestrial orchids were more common than epiphytes. The role of orchids in succession has received little attention. Changes in orchid communities on the Krakatau Islands during the last 115 years provide an insight into colonisation patterns in a vegetation regenerating towards tropical rain forest. In surveys of the Krakataus between 1981 and 1998, at least 63 species of orchids colonising the islands have been noted. All orchids on Krakatau Islands are wind-dispersed. Rakata, the highest and least disturbed island in the group, carries the greatest diversity of orchids. The orchid flora of Krakatau is a disharmonic subset of the mainland (Southeast Asia) pool and certain genera e.g. Agrostophyllum, Dendrobium, Eria, and Grammatophyllum are relatively under-represented. Comparison between Javanese and Sumatran species, and the proportion of species common between the islands of Sebesi-Sebuku and the Krakatau Islands, indicates that the orchid flora of the Krakataus has been chiefly derived from Java rather than from Sumatra, even though two 'stepping stone' islands exist between the Krakataus and Sumatra.
\end{abstract}

\section{Introduction}

After the eruption of the volcanic island Krakatau in the Sunda Strait in 1883, it is believed that no living thing existed on the three remaining islands. The flora of the Krakatau Islands has been investigated ever since the first higher plant was observed growing on the islands within 3 years after the eruption. The documenting of plant colonisation on the islands, from the earliest successional stage, has provided a unique record of island recolonisation. The vegetation studies on the Krakataus thus have a special place in the theory of primary succession of bare ground (Docters van Leeuwen 1936, Borssum Waalkes 1960, Whittaker \& Bush 1993). A survey made in 1896, 13 years after the explosion, revealed that among the pioneer plant species, three orchids were found on Krakatau. One year later (1897), four terrestrial species of orchids were collected (Docters van Leeuwen 1936). By 1935 the number of species of orchids reached 25 and by 1989 the number of species recorded on the islands had increased to 59 (App. $1,2,3)$. The species record of orchids thus increased continuously in conjunction with vegetation succession on the islands.

Orchids are among the most numerous and attractive flowering plants in the tropical region. They can be found in a variety of habitats from open grasslands, dense forests, hot and cold deserts, on damp or dry areas, on trees or rocks that hang over the ocean and are subjected to salt spray, underground, on floating vegetation and other habitats that can support flowering plants (Arditti 1992). They grow in mountains, flatlands and valleys. They can grow in the soil (terrestrial) and on other plants as epiphytes. A number of terrestrial orchids can colonise bare soil as pioneers, as noted for the Krakatau Islands by Docters van Leeuwen (1936). 
Despite their importance in the colonising flora, the occurrence of orchids in the Krakatau Islands appears to have received relatively little attention. The Krakatau Islands provide a unique opportunity to assess the role of orchids in a colonisation record spanning a period of over 100 years. This paper reports on records of orchid colonisation on the islands, since the earliest succession stage. It is of interest to compare the species establishment of the early succession stages and the recent developed forest situation.

\section{Study Area}

The Krakatau Islands are situated in about the middle of Sunda Strait, about $40 \mathrm{~km}$ from each of the biologically rich mainlands of Java and Sumatra (Fig.1). Three of the four islands, Rakata, Sertung and Panjang are believed to have been totally sterilized by the devastating eruption of Krakatau in 1883. The fourth island, Anak Krakatau, emerged from the submarine caldera of Krakatau in about 1930. This youngest island suffered self-devastating eruptions in 1952/3, 1967/8, 1992-4, with the most recent occurring in 1995-6. Rakata, with an elevation of about $780 \mathrm{~m}$, is the southern half of what was Krakatau's highest volcano. Rakata, Sertung and Panjang are now covered by species-poor mixed forest. Anak Krakatau's vegetated area is only some $17 \%$ concentrated along the eastern coastal areas. The remainder of the island is composed of barren ash and lava flows.

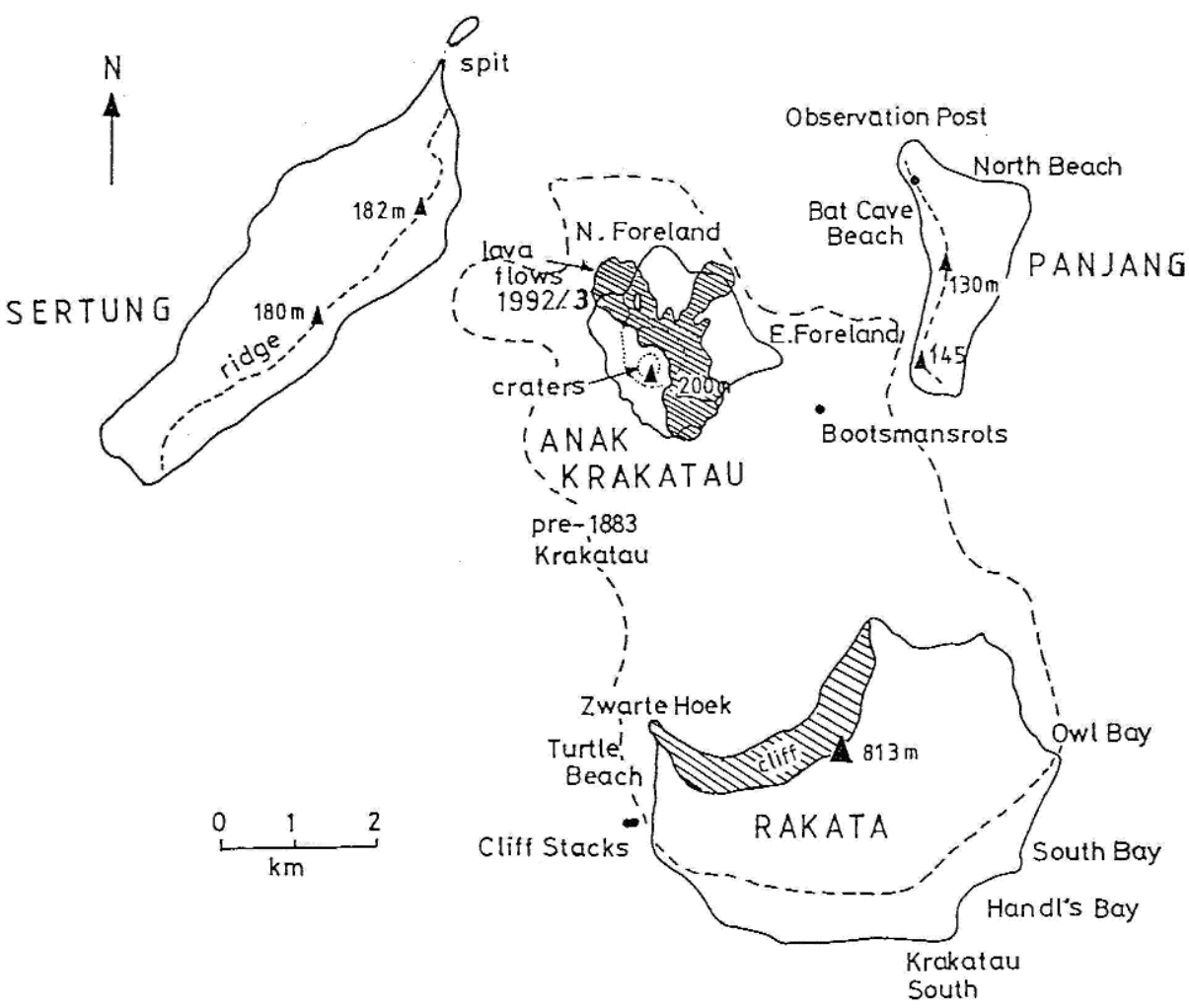

Fig. 1. The Krakatau Islands in 1994 showing the tip of Sertung spit which split off and then disappeared in 1995. Broken lines indicate the island shape before the 1883 eruption. 


\section{Methods}

The analyses are based upon the complete flora lists for Rakata, Sertung, and Panjang (Docters van Leeuwen 1936, Borssum Waalkes 1960, Whittaker et al. 1989, Partomihardjo 1995). Unpublished flora data from the complete lists of various expeditions are also included (University groups from Kagoshima, Oxford, La Trobe). The flora of Anak Krakatau was taken from investigations by the author since 1981 (Partomihardjo et al. 1992, Partomihardjo 1995). The floristic surveys of Krakatau have been somewhat irregular and not all surveys are comparable in collecting effort, therefore some surveys have been grouped together for comparative purposes (as Whittaker et al. 1989, Partomihardjo 1995). The period 1992 to 1998 is treated as a single block for the older islands because over this period a fairly comprehensive survey has been carried out. The number of species of flowering plants recorded from various expeditions between 1989 and 1998 currently stands at 306, consisting of 65 orchids and 131 other species of Spermatophytes, although it should be stressed that these are conservative estimates.

Four plots of $30 \times 30 \mathrm{~m}$ were established, one each at 10, 100, 300 and $500 \mathrm{~m}$ a.s.l. and one plot of $20 \times 20 \mathrm{~m}$ at $700 \mathrm{~m}$ a.s.l. on Rakata Island, to observe the occurrence of epiphytic orchids at different altitudes. The plots were established in 1992 and almost every two years were monitored.

\section{Results and Discussion}

\section{The history of orchid colonisation}

The first orchids: Among the first higher plants to arrive on the Krakataus were three orchids. Cymbidium finlaysonianum, a common epiphytic orchid in the Indo-Malayan region, was found by Boerlage on Panjang in 1896, where it grew on a steep ravine wall. Spathoglottis plicata and Arundina graminifolia, both terrestrial pioneer orchids, were also recorded in 1896. One year later Penzig found two of them, growing on Rakata (Docters van Leeuwen 1936). Besides the three species mentioned above, he also recorded Phayus sp. on Rakata and Panjang. Four terrestrial orchids in total were found on all three islands, and they have been recorded in all subsequent surveys (Docters van Leeuwen 1936). During the first 20 years, the epiphytic orchids were restricted to C. finlaysonianum, whilst five species of terrestrial orchids were recorded. In 1908, Backer reported Nervilea aragoana growing in the south east of Rakata above $200 \mathrm{~m}$, and collected Eulophia graminea on the beach at Zwarte Hoek (Rakata) and on Sertung. The Arundina and Spathoglottis were common in 1908, the latter species in particular covered steeply sloping areas. These heliophilous plants are restricted to areas sparsely covered with vegetation and to the recent landslides. Although the shade of the developing tree layer affected the heliophilous orchids, this denser shading and the larger quantities of humus made it possible for a number of other terrestrial orchids to settle. Seven species of orchids had colonised the Krakataus by 1908, two of them were terrestrial, A. graminifolia and S. plicata, and the others were epiphytes. These epiphytic orchids have been a continuous component of the epiphytic flora of Krakatau since their arrival. Dendrobium crumenatum and D. mutabile, are epiphytic orchids, which successfully colonised the canopy of the beach forest. Another important orchid first found in 1905-08 was an Eria species, which Docters van Leeuwen (1936) reported from both the beach and the 'grass-jungle' before 1919. It was also observed growing as an epiphytic orchid, and by the end of the 1920s it had become a common component of the epiphytic flora on the islands. There were a number of new epiphytic species 
growing in the higher part of Rakata, especially in the Cyrtandra shrubland. In 1934, Boedijn found a holo-saprophytic orchid, Galeola kuhlii growing on a decayed tree trunk on Rakata (Docters van Leeuwen 1936).

Early diversification: In the early 20th century, as the Krakatau flora continued to diversify on all three islands, the Orchidaceae was the most speciose family with 17 species being recorded as of 1920. A young forest developed on each of the islands offering support for the epiphytic orchids. Docters van Leeuwen (1936) reported that the early-arrival air-dispersed species tended to spread to all three islands by the early 1930s, a pattern evident in the orchid data set presented in Table 1 . The number of orchids species continuously increased, and by 1933 it reached 31. The colonisation of the orchid flora on the Krakataus was relatively rapid within the early stage of the succession process because the distance from the mainland of Java is only $40 \mathrm{~km}$. Most orchids recorded in the early diversification were terrestrial. Because of the limited availability of the usual tree habitat, the epiphytic orchids recorded during the early stages grew on rock or ash faces, particularly in steep gullies.

\begin{tabular}{|c|c|c|c|c|c|c|c|c|c|}
\hline Event & 1883 & 1886 & 1896 & 1908 & 1932 & 1951 & 1979 & 1989 & 1998 \\
\hline Explosion & $x$ & - & - & - & - & - & - & - & - \\
\hline Number of species recorded & - & 0 & 3 & 5 & 21 & 10 & 15 & 17 & 40 \\
\hline $\begin{array}{l}\text { Elapsed time, years since } \\
\text { Previous count } \\
\text { Explosion }\end{array}$ & - & - & $\begin{array}{l}10 \\
13\end{array}$ & $\begin{array}{l}12 \\
25\end{array}$ & $\begin{array}{l}24 \\
49\end{array}$ & $\begin{array}{l}18 \\
68\end{array}$ & $\begin{array}{l}28 \\
96\end{array}$ & $\begin{array}{l}10 \\
106\end{array}$ & $\begin{array}{l}9 \\
115\end{array}$ \\
\hline $\begin{array}{l}\text { Increase in species number } \\
\text { Previous count } \\
\text { Explosion }\end{array}$ & - & - & $\begin{array}{l}3 \\
3\end{array}$ & $\begin{array}{l}1 \\
5\end{array}$ & $\begin{array}{l}30 \\
31\end{array}$ & $\begin{array}{l}13 \\
36\end{array}$ & $\begin{array}{l}11 \\
44\end{array}$ & $\begin{array}{l}32 \\
55\end{array}$ & $\begin{array}{l}43 \\
65\end{array}$ \\
\hline $\begin{array}{l}\text { Increase per year since } \\
\text { Previous count } \\
\text { Explosion }\end{array}$ & - & - & $\begin{array}{l}0.3 \\
0.23\end{array}$ & $\begin{array}{l}0.08 \\
0.2\end{array}$ & $\begin{array}{l}1.2 \\
0.5\end{array}$ & $\begin{array}{l}0.7 \\
0.5\end{array}$ & $\begin{array}{l}0.4 \\
0.5\end{array}$ & $\begin{array}{l}3.2 \\
0.5\end{array}$ & $\begin{array}{l}4.8 \\
0.56\end{array}$ \\
\hline
\end{tabular}

Actual and cumulative number of orchid species on the Krakatau Islands from various expedition records are summarised in Table 2. The epiphytic orchid species of the Krakataus had increased to about 40 species (61\% of the total orchids flora) by 1994, although some of the early epiphytic orchids species may have become extinct from the islands (Appendix 1). Over the period of 1979 to 1989 the increase of species was relatively slow, compared to the total enrichment of vascular plants on the islands, in particular for the terrestrial orchids. This might be due to the seasonal vegetative appearance of the terrestrial orchids, which makes it difficult to detect them in certain periods of the year. However, in the 1991-1993 field survey, four species of epiphytic orchids Eria verruculosa, Flickingeria angustifolia, Glomera erythrosma and Pholidota articulata were newly recorded. Based on herbarium collections, the two species Eria verruculosa and Glomera erythrosma are known so far only from Java.

Partomihardjo et al. (1992) mentioned that vegetation communities on Anak Krakatau are still in a very early stage of succession, where diversity of potential host trees is very low. The first orchid recorded from Anak Krakatau since it emerged from the sea in 1930 was Dendrobium crumenatum. This epiphytic orchid was found growing on the cliff of an eroded gully. Six additional species of orchids were recorded on the island 
from 1981 to 1991 (Appendix 2). The epiphytic orchids Acriopsis javanica and Cymbidium finlaysonianum were found growing at the base of clumps of wild sugarcane (Saccharum spontaneum: Poaceae), and in recent observations they were recorded with $C$. pubescens, on S. spontaneum. This condition reflects the limited availability of their usual tree habitat. In the early stages of succession on the Krakatau Islands, epiphytic orchids did not grow on trees because there were none. Whittaker et al. (1992) demonstrated that the forest communities on the Krakataus are still accumulating new families and genera of plants. The forests are still relatively immature, with a large potential pool of immigrants. Vascular plants still continue to colonise the islands.

Table 2. Orchids on Krakatau Islands: cross-tabulation of terrestrial and epiphytic orchids, with island combinations indicated by the letter codes: $\mathrm{R}=\mathrm{Rakata}, \mathrm{S}=$ Sertung, $\mathrm{P}=$ Panjang.

RSP

RS

RP

SP

$\mathbf{R}$

$S$

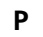

1886-1934

Terrestrial

Epiphyte

Total

1935-1979

Terrestrial

Epiphyte

Total

$\begin{array}{ll}5 & 4 \\ 1 & 2 \\ 6 & 6\end{array}$

2

0

2

0
0
0

7
12
19

$\begin{array}{ll}0 & 0 \\ 0 & 0 \\ 0 & 0\end{array}$

0
0
0

0
0
0

8
10
18

$\begin{array}{lll}0 & 0 & 18 \\ 1 & 0 & 16 \\ \mathbf{1} & \mathbf{0} & \mathbf{3 4}\end{array}$

1980-1998

Terrestrial

Epiphyte

Total

$\begin{array}{rrr}0 & 0 & 8 \\ 0 & 0 & 10 \\ \mathbf{0} & \mathbf{0} & \mathbf{1 8}\end{array}$

1886-1998

Terrestrial

Epiphytes

Total

$\begin{array}{ll}5 & 3 \\ 3 & 1 \\ 8 & 4\end{array}$

$\begin{array}{ll}1 & 1 \\ 0 & 0 \\ \mathbf{1} & \mathbf{1}\end{array}$

5
26
31

$\begin{array}{lll}1 & 0 & 16 \\ 0 & 0 & 30 \\ \mathbf{1} & \mathbf{0} & \mathbf{4 6}\end{array}$

Over the period 1951 to 1983, gradual vegetation change took place on Rakata, from a poor mixed secondary forest to a taller forest with a more diverse canopy. On Panjang and Sertung, which were disturbed by the eruption of Anak Krakatau, the forests remained less diverse, with lower, sparser canopy than in forests of Rakatau. The vegetational development was accompanied by an increase in the number of plant species. This increase in vegetation diversity was accompanied by a build-up in the diversity of orchid species, which mostly are epiphytes. Actual and cumulative number of orchid species on the Krakatau Islands from various expeditions are summarized in Figure 2. 


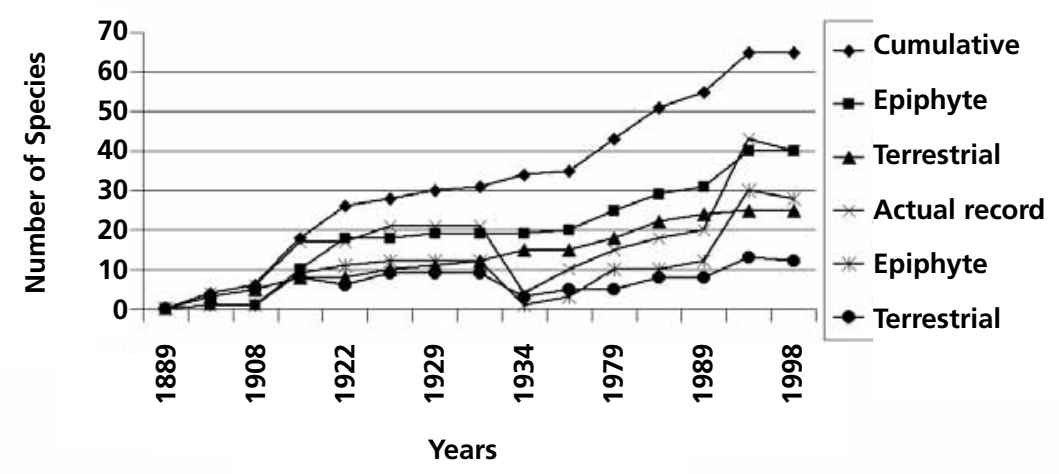

Fig. 2. Colonisation of orchids on the Krakatau Islands. Data recorded from various expeditions.

Ash-fall and species depletion of orchids: Since 1934, orchids colonisation on Rakata has continued at a faster rate than on Sertung and Panjang (Table 2), increasing the disparity in species diversity between the islands. Of the 45 species of orchids currently recorded on the three older islands, all occur on Rakata, three on Panjang and two on Sertung (Table 2). These data are consistent with the whole flora pattern and are interpreted as a consequence, in part, of repeated disturbance by post-1930 ash falls from Anak Krakatau, depressing colonisation (Whittaker et al. 1989, 1992, Bush et al. 1992, 1995). The thick ash accumulation on Panjang and Sertung, followed by a severe dry season, will possibly have killed all ground cover vegetation including the orchids. Consequently, species with local distributions on Sertung and Panjang, particularly terrestrial orchids, may have been eliminated by these disturbances, whereas Rakata has been unaffected.

The record of orchids in the forest of Krakatau after 115 years: The commonest orchid within the interior forest is Dendrobium crumenatum. This species is also known as the most cosmopolitan and abundant epiphytic plant throughout the islands. First recorded on Rakata and Sertung in 1920, this orchid was not recorded on Panjang until 1951. Grammatophyllum speciosum, a giant epiphytic orchid that might occur growing on the ground in early colonisation, is unlikely to be missed by any visitor: was recorded as epiphytic on the beach vegetation in 1994 and 1998; was not found on Sertung until 1991; and is not documented from Panjang. Recently, the commonest orchid in Panjang is Dendrobium crumenatum. This species was also recorded from Anak Krakatau in 1981, growing on the wall of gullies. Judging by its population size on Panjang and Sertung, it seems to have colonised recently. These inter-island differences of orchids are most parsimoniously explained by the disturbance regimes of Anak Krakatau activities. Most of the terrestrial orchids both on Sertung and Panjang were covered by the accumulation of ash fall during each eruption of Anak Krakatau. In contrast, the arboreal orchids are mostly found in the cloud forest of Rakata, i.e. the summit area down to about $500 \mathrm{~m}$, and the same is true for other epiphytic plants. Despite an overall increase in the abundance of epiphytes as the forest becomes moister above $500 \mathrm{~m}$ elevation, the number of terrestrial orchids is also noticeably larger. 
A means of estimating forest maturity is based on epiphytes, mostly consisting of orchids. It has been suggested that in well-established forests epiphytic species (mostly orchids) are abundant, and that as the forest matures epiphytic species become proportionally more abundant, particularly on trees of $>30 \mathrm{~cm} \mathrm{dbh}$ (Benzing 1981). In mature dipterocarp forests at Wanariset, East Kalimantan, $50 \%$ of the epiphytes were orchids (Partomihardjo 1995). It has been mentioned that the epiphytic orchids have a wide distribution within the trees. For example, epiphytic orchids can be found to grow on the terminal branches of the canopy layer to the very base of large trees. Interestingly, the rate of increasing of epiphytic and terrestrial orchids is somewhat anomalous.

Dispersal mechanisms and limits to colonisation: The cumulative survey data of orchids from 1883 to 1998 shows 24 to 41 species of terrestrial and epiphytic respectively. On Krakatau, orchids are assumed to have colonised through wind dispersal (anemochorous). Dressler (1981) suggested that most orchid seeds are wellsuited for wind dispersal. Measurements of the air space inside seeds in the laboratory and the time needed for them to fall $1.5 \mathrm{~m}$ in a glass tube, indicate that long-distance travel by air is clearly possible for orchid seeds (Arditti 1992). Air transport of orchid seeds on the feathers or legs of birds has been suggested by Went (1990) and Ridley (1930), although Arditti (1992) argued that the chance is very small. This evidence is supported by the fact that large numbers of common species of orchids have no correlation with the bird migration roots. Wind dispersal seems the only mode of orchid dispersal, because all species recorded on the Krakataus have capsules that open and release the seeds free to float on the air. Dispersal by sea as suggested by Ridley (1930) seems very unlikely.

Most orchids are very sensitive to altitude, which really means temperature and moisture regimes (Comber 1990). Because the mountain on Krakatau is relatively low, there is only a narrow range of temperatures available to suit the needs of many orchids. Moisture condensation in the form of rain or mist on the highest point of Rakata is much greater than at the lower altitudes, because this island is surrounded by sea, and it is continuously swept by moist winds which cool as they rise and release their rain water on the summit area. So it has been found that most of the orchids recorded in Krakatau grow exclusively on the trunks and branches of trees at high altitude, where they only have a few ferns as competitors.

Sebesi is the closest island to the Krakatau group and is of similar altitude to Rakata. Sebesi was less badly damaged by the eruptions of 1883. As of 1921 its inland forests were in a more advanced state of recovery than on Krakatau, and possessed a larger number of orchids (Docters van Leeuwen 1936). At least nine other species occurring there have not yet been recorded for Krakatau. This simple comparison suggests that further additions to the Krakatau orchid assemblage can be expected.

Altitudinal distribution and species richness of epiphytic orchids: At higher altitudes on Rakata a greater diversity of epiphytic orchids is present than in lower areas. To investigate the altitudinal variation of the orchid species, plots were set up at 10, 100, 300, 500 and $700 \mathrm{~m}$ a.s.l. (Table 3). The total number of species counted within each plot were 2, 2, 7, 9 and 14 species respectively. The population was highest in the $500 \mathrm{~m}$ plot, with the number of individuals declining to 50.75 per $100 \mathrm{~m}^{2}$ at the summit. In the $300 \mathrm{~m}$ plot there were only 8.5 individuals per $100 \mathrm{~m}^{2}$. An altitudinal preference was evident in some species of orchids. The epiphytic species Appendicula reflexa and Pholidota articulata were recorded in the highest plot only. The common species Dendrobium crumenatum tends to be more abundant in the lower areas, while D. mutabile grows at higher altitude. 
Table 3. Epiphytic orchids recorded at different altitudes in forest plots on Rakata

\begin{tabular}{|c|c|c|c|c|c|}
\hline Species & $\begin{array}{l}10 \mathrm{~m} \\
\text { a.s.l. }\end{array}$ & $\begin{array}{c}100 \mathrm{~m} \\
\text { a.s.l. }\end{array}$ & $\begin{array}{c}300 \mathrm{~m} \\
\text { a.s.l. }\end{array}$ & $\begin{array}{c}500 \mathrm{~m} \\
\text { a.s.l. }\end{array}$ & $\begin{array}{c}700 \mathrm{~m} \\
\text { a.s.l. }\end{array}$ \\
\hline Agrostophyllum bicuspidatum & 0 & 0 & 0 & 4 & 0 \\
\hline Agrostophyllum denbergerii & 0 & 0 & 0 & 2 & 5 \\
\hline Appendicula reflexa & 0 & 0 & 0 & 0 & 66 \\
\hline Bulbophyllum purpurascens & 0 & 0 & 7 & 99 & 1 \\
\hline Bulbophyllum unguiculatum & 0 & 0 & 0 & 16 & 2 \\
\hline Bulbophyllum sp. & 0 & 0 & 3 & 0 & 8 \\
\hline Coelogyne rochussenii & 0 & 0 & 0 & 7 & 0 \\
\hline Dendrobium accuminatissimum & 0 & 0 & 0 & 14 & 1 \\
\hline Dendrobium sp. & 0 & 0 & 0 & 0 & 1 \\
\hline Dendrobium crumenatum & 88 & 95 & 24 & 22 & 0 \\
\hline Dendrobium mutabile & 75 & 12 & 19 & 295 & 96 \\
\hline Dendrobium secundum & 0 & 0 & 3 & 0 & 1 \\
\hline Eria retusa & 0 & 0 & 0 & 0 & 1 \\
\hline Flickingeria angustifolia & 0 & 0 & 0 & 2 & 14 \\
\hline Malaxis latifolia & 0 & 0 & 2 & 0 & 1 \\
\hline Phaius tankervilleae & 0 & 0 & 0 & 0 & 1 \\
\hline Pholidota articulata & 0 & 0 & 0 & 0 & 5 \\
\hline Thixspermum merguense & 0 & 0 & 2 & 0 & 0 \\
\hline Total of species per plots & 2 & 2 & 7 & 9 & 14 \\
\hline Total of individuals per plot & 161 & 107 & 60 & 461 & 203 \\
\hline
\end{tabular}

The greater number of orchid species in upland Rakata, compared to the lowlands, might be explained in terms of the wetter conditions on the upper slopes. The forest above $500 \mathrm{~m}$, as indicated by the moss communities, can be regarded as cloud forest (Whittaker et al. 1989). The large increase in population size and species richness in the $500 \mathrm{~m}$ plot compared to the $300 \mathrm{~m}$ plot is correlated with an increase in daily cloud cover and humidity at this altitude. Therefore, the species richness of orchids in the mossy forest of Rakata is not very different from the summit area, although the population density in the latter is much lower. Whitmore (1992) noted that moisture from cloud and mist are important for colonisation of epiphytes (orchids). The increase in species richness with altitude in the series of closed-forest plots on Rakata can be attributed to increasing average daily period of cloud cover and humidity, with increasing altitude. It is doubtful that the humidity associated with cloud cover alone accounts for the high diversity of the epiphytic orchids on Rakata, for it is evident that many integrated factors affect the epiphytic population. Although there is no detailed study, it seems likely that the abundance of mosses covering the bark, with their considerable water-holding capacity, promote the germination of epiphytic orchid seeds. In the mainland areas (Java and Sumatra) such altitudes are usually free from fog and the cloud belt is situated at an altitude of about $2000 \mathrm{~m}$. This phenomenon of lowered and compressed zonations on islands may be caused by increasing air humidity due to the surrounding sea-water (van Steenis 1972): changes in temperature, relative humidity and rain-fall all being related to small altitudinal differences. 
Orchids on Sebesi-Sebuku and the Krakatau Islands: In 1996, 17 species of orchids were collected from Sebesi, bringing the cumulative total for the island to 21 species from 7 genera. Prior to the 1996 survey, 15 species of orchids were recorded from Sebesi in 1886 (Docters van Leeuwen 1936). Of these, 11 species were also found in 1996. This island was less badly damaged by the eruptions of 1883 , than were the Krakatau Islands themselves. As of 1921, its inland forests were in a more advanced state of recovery than Krakatau, and possessed a larger number of orchids (Docters van Leeuwen 1936). At least eight other species occurring there were not recorded for Krakatau at that time. This simple comparison indicates that further additions to the Krakatau orchids can be expected.

On the Krakatau Islands, 64 species of orchids consisting of 7 species of terrestrial and 58 species of epiphytic orchids were recorded during the period from 1886 to 1996.

Common species on Sebesi-Sebuku and Krakatau Islands: Four species out of the 17 species that were recorded in 1996 on Sebesi-Sebuku have never been recorded from the Krakatau Islands (Table 4), and all species of orchid found on Krakatau were also recorded from Java. This suggests that there have been more frequent dispersals of orchid species from Java to the Krakatau and then on to Sebesi-Sebuku, than in the opposite direction. According to Comber (1990), the flowering season of orchids on Java mostly occurs between May and June. The capsule fruits ripen during the end of dry season from August to September. During this season easterly winds are prominent. Consequently the species of orchids colonising the Krakataus appear likely to be biased towards Javan elements rather than those of Sebesi-Sebuku.

Table 4. Comparison between species belonging to Javanese and Sumatran components in the proportion of species common on Sebesi and Krakatau Islands

$\begin{array}{lcc}\text { Distributional category } & \text { Recorded on Sebesi/Sebuku } & \text { Recorded on Krakatau Islands } \\ \text { Javanese } & 13(80 \%) & 9(75 \%) \\ \text { Sumatran } & 4(20 \%) & 0(0.0 \%) \\ \text { Total } & \mathbf{1 7 ( 1 0 0 \% )} & \mathbf{9 ( 7 5 \% )}\end{array}$

\section{Conclusion}

This study finds that orchids colonising in the immediate aftermath of the eruption episode were drawn from the terrestrial group. The appearance of epiphytic orchids in the early succession processes was associated with grass clumps featuring as temporary host plants. The availability of host trees undoubtedly promoted the colonisation rate of epiphytic orchids, while deadwood provided substrates for saprophytic species establishment. As generally the case for forest taxa, which are still accumulating, new records of orchids are still being made. However, the colonisation rate is likely to slow since the natural forests of surrounding areas on mainland Java and Sumatra are being depleted.

The wide-spread distribution of most orchids throughout the islands, indicates that dispersal mode is not the limiting factor for orchid colonisation. The distribution of species richness seems to be affected by moisture availability and habitat quality. The lower and less diverse population of orchids on Panjang and Sertung is probably due to the volcanic activities of Anak Krakatau and the topography of the islands, which lacking high upland regions are less suitable for orchid establishment. 


\section{Acknowledgments}

Special thanks goes to the Flora Malesiana Foundation for inviting me to participate in the Flora Malesiana Symposium in Sydney, Australia 2001, and I am grateful to the Research Center for Biology, Indonesian Institute of Sciences (LIPI) for permission to attend the Symposium. I wish to express my hearty thanks to Dr. E. de Vogel (Leiden Botanical Gardens, the Netherlands) who critically read the draft. Special thanks to Dr. Rob Whittaker (School of Geography and the Environment, Oxford University) for comments on the draft. My thanks are also extended to Oxford and LaTrobe Universities for inviting me to join their expedition to the Krakatau Islands.

\section{References}

Arditti, J. (1992) Fundamentals of Orchid Biology. (John Wiley \& Sons: New York, Chichester, Brisbane, Toronto, Singapore).

Benzing, D.H. (1981) Bark surfaces and the origin and maintenance of diversity among angiosperm epiphytes: a hypothesis. Selbanya 5: 248-255.

Borssum Waalkes, J.van (1960) Botanical observation on the Krakatau Islands in 1951 and 1952. Ann. Bogor. 4: 5-63.

Bush, M.B., Whittaker, R.J. \& Partomihardjo, T. (1992) Forest development on Rakata, Panjang and Sertung: contemporary dynamics (1979-1989). GeoJournal 28: 180-186.

Bush, M.B., Whittaker, R.J. \& Partomihardjo, T. (1995) Colonisation and succession on Krakatau, an analysis of the guild of vining plants. Biotropica 27: 355-372.

Comber, J.B. (1990) Orchids of Java. (Bentham-Moxon Trust, Royal Botanic Gardens: Kew).

Docters van Leeuwen,W.M. (1936) Krakatau 1883-1933. A Botany. Annales du Jardin Botanique de Buitenzorg 46-47: 1-506.

Dressler, R.L. (1981) The Orchids: Natural history and classification. (Harvard University Press: Cambridge, Mass.).

Gandawidjaja, D \& Arditti, J. (1983) The orchids of Krakatau: Evidence for a Mode of Transport. Annals of Botany 52: 127-130.

Partomihardjo, T. (1995) Studies on the ecological succession of plants and their associated insects on the Krakatau Islands, Indonesia. Dissertation for the degree of Ph.D. submitted to the United Graduate School of Agricultural Sciences, Kagoshima University, Japan.

Partomihardjo, T., Mirmanto, E. \& Whittaker, R.J. (1992) Anak Krakatau's vegetation and flora circa 1991, with observations on a decade of development and changes. GeoJournal 28: 233-246.

Ridley, H.N. (1930) The Dispersal of Plants throughout the World. (L. Reeve: Ashford, Kent).

Steenis, C.G.G.J.van (1972) The mountain flora of Java. (E.J. Brill: Leiden).

Went, F.M. (1940) Sosiologie der Epiphyten eines tropiscen Urwaldes. Ann. jard. Bot. Buitenz. 50: 1-98.

Whitmore, T.C. (1992) An Introduction to Tropical Rain Forests. (Clarendon Press: Oxford).

Whittaker, R.J., Bush, M.B. \& Richards, K. (1989) Plant colonisation and vegetation succession on the Krakatau Islands, Indonesia. Ecological Monograph. 59(2): 59-123.

Whittaker, R.J., Bush, M.B., Partomihardjo, T., Asquith, N. \& Richards, K. (1992) Ecological aspects of plant colonisation of the Krakatau Islands. GeoJournal, 28 (2) : 201-211.

Whittaker, R.J. \& Bush, M.B. (1993) Dispersal and establishment of tropical forest assemblages, Krakatoa, Indonesia. In J. Miless and D.H.W. Walton (eds), Primary succession on land. Special Publication Number 12, British Ecological Society. (Blackwell Scientific: Oxford). 
Appendix 1. The species list of Orchidaceae recorded on the Krakatau Islands (1883-1998) from various expeditions. Survey data are combined: R=Rakata, $\mathrm{S}=$ Sertung, P=Panjang. (Anak Krakatau data are listed separately in Appendix 2).

Species

Acanthephippium parviflorum Hassk.

Acriopsis javanica Reinw. ex Bl.

Agrostophyllum bicuspidatum J.J.Sm.

Agrostophyllum denbergeri J.J.Sm.

Appendicula reflexa BI.

Arundina graminifolia (D.Don)Hochr.

Bulbophyllum purpurascens T.\& B.

Bulbophyllum unguiculatum Rchb.f.

Bulbophyllum sp.

Calanthe angustifolia (BI.)Lindl.

Calanthe sp.

Coelogyne longifolia (BI.)Lindl.

Coelogyne rochusseni De Vr.

Cymbidium aloifolium (L.)Sw.

Cymbidium bicolor Lindl.

Cymbidium finlaysonianum Lindl.

Dendrobium acuminatissimum Lindl.

Dendrobium crumenatum Swartz

Dendrobium mutabile Lindl.

Dendrobium secundum Lindl.

Dendrobium sp.

Eria annulata Bl.

Eria oblitterata Rchb.f.

Eria retusa Rchb.f.

Eria verruculosa J.J.Sm.*

Eulophia graminea Lindl.

Eulophia macrostachya Lindl.

Eulophia nuda Lindl.

Eulophia zollingeri J.J.Sm.

Flickingeria angustifolia (BI.)A.D. Hawkes

Galeola nudifolia Lour.

Geodorum densifflorum (Lamark)Schltr.

Glomera erythrosma Bl.

Goodyera colorata (BI.)BI.

Goodyera rubens-grandis (Bl.) Bl.

Goodyera sp.

Grammatophyllum speciosum BI.

Habenaria sp.

Liparis viridiflora Lindl.

Liparis wrayii Hook.f.

Liparis sp.

Macodes petola Lindl.

Malaxis latifolia Sm.

Nervilia aragoana Gaudich.

Nervilia punctata Makino

Oberonia monstruosa Lindl.

Oberonia sp.

Peristylus goodyeroides Lindl.

Peristylus gracilis Bl.

Peristylus grandis $\mathrm{BI}$

Phaius tankervilliae (Banks ex I.Herit)BI.

Phaius sp.

Pholidota articulata Lindl.

Pholidota imbricata Hook.

Podochilus gracilis Lindl.

Spathoglottis plicata BI.

Taeniophyllum sp.

Thrixspermum merguense (Hook.f)O.Kuntz

Thrixspermum sp.1

Thrixspermum sp.2

Trichotosia annulata Bl.

Tropidia curculigoides Lindl.

Vrydagzynea albida BI.

Vrydagzynea sp.

Zeuxine gracilis $\mathrm{BI}$

Total

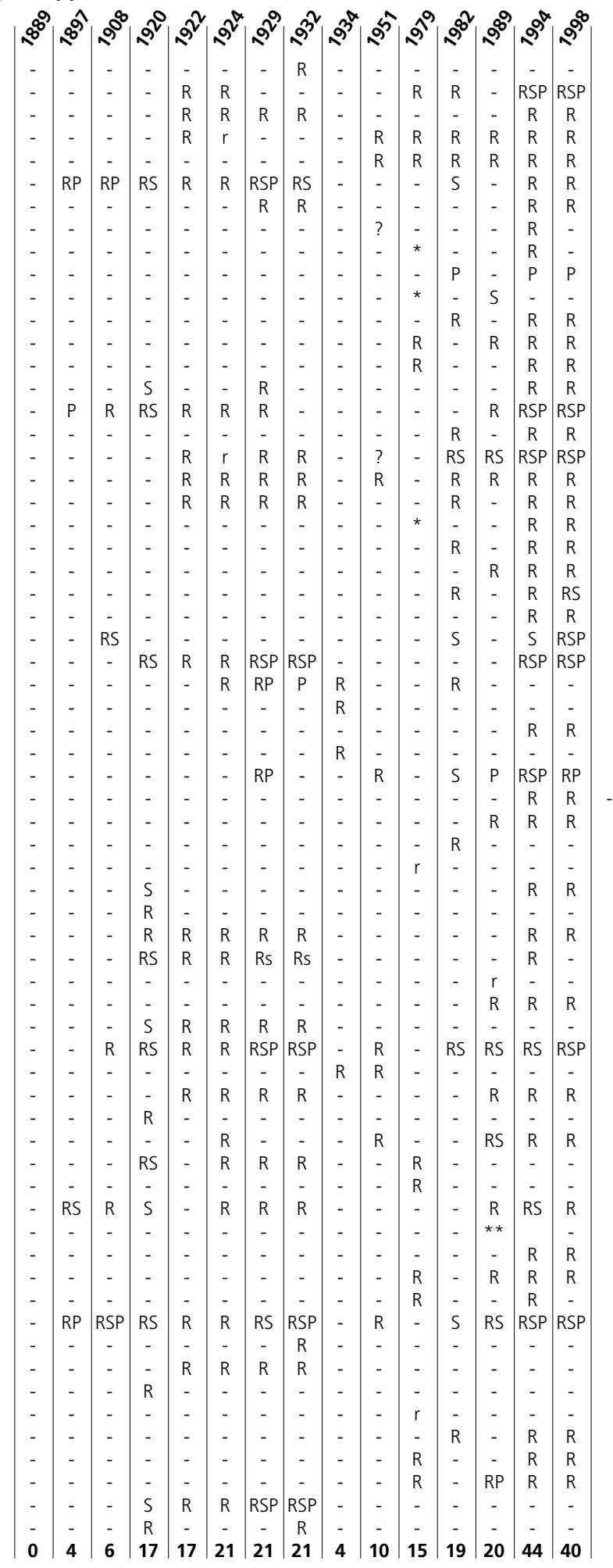


Appendix 2. List of species of orchids recorded on Anak Krakatau from various expeditions.

Species

Acriopsis javanica Reinw.

Calanthe sp.

Cymbidium finlaysonianum Lindl

Eulophia graminea Lindl.

Eulophia pulchhra (Thou.) Lindl.

Spathoglottis plicata BI.
Dendrobium crumenatum Swartz.

\section{$\begin{array}{lllllllllll}1963 & 1971 & 1979 & 1981 & 1982 & 1983 & 1989 & 1990 & 1991 & 1994 & 1998\end{array}$}

Appendix 3. List of species of orchids recorded on Sebesi-Sebuku and common to Krakatau Islands (from van Leeuwen (1921) and author's data for 1989, 1994).

\section{Species}

Sebesi-Sebuku

\section{Krakatau}

Agrostophyllum majus J.J.Sm.

Bulbophyllum multiflorum (Breda) Krzl.

Bulbophyllum scheffleri Schlechter.

Calanthe zollingeri Rchb.f.

Coelogyne miniata Lindl.

Corymbis veratrifolia Rchb.f.

Cymbidium finlaysonianum Lind.

Dendrobium crumenatum Lindl.

Dendrobium mutabile Lindl.

Dendrobium tenellum Lindl.

Eulophia macrostachya Lindl.

Eulophia squalida Lindl.

Goodyera colorata Bl.

Liparis sp.

Macodes petola Lindl.

Nervilia aragoana Gaudich.

Oberonia monstruosa Lindl.

Phaius tankervillae (Banks ex I.Herit) BI.

Spathoglottis plicata BI.

Vrydagzynea sp.

Zeuzine sp. 